\title{
Contract of Adhesion and Conceptional Changes in Russian Contract Law
}

\author{
Andrey F. Baculin ${ }^{1}$, Anna V. Kuzmina ${ }^{1} \&$ Olga I. Miagkova ${ }^{2}$ \\ ${ }^{1}$ Mari State University, Yoshkar-Ola, Russia \\ 2 The Russian Presidential Academy of National Economy and Public Administration, Moscow, Russia \\ Correspondence: Anna V. Kuzmina, Faculty of Law, Mari State University, Lenin Square 1, Yoshkar-Ola, \\ 424000, Russia.
}

$\begin{array}{lc}\text { Received: February 21, } 2015 & \text { Accepted: March 15, } 2015 \quad \text { Online Published: April 29, } 2015 \\ \text { doi:10.5539/res.v7n8p15 } & \text { URL: http://dx.doi.org/10.5539/res.v7n8p15 }\end{array}$

\begin{abstract}
The institute of the contract of adhesion is suffering changes in Russian Contract Law nowadays. Moreover, the concept of unfair terms has been recently introduced to court practice. In this article the authors examine legal nature of these two institutes and make critical suggestions on the development of the legislation regulating contract of adhesion based on the experience of foreign countries.
\end{abstract}

Keywords: contract of adhesion, inequality of bargaining power, good faith, unfair contract terms

\section{Introduction}

The inclusion of norms regulating contract of adhesion in article 428 of the Civil Code of the Russian Federation in 1995 has become one of the most important constituents of the development of the whole Russian Contract Law in accordance with the principles of freedom of contract, equality of parties and good faith.

This legal institute is of current interest not mainly because of its unfamiliarity to Russian legislation, but because of lack of clear and unique understanding of its meaning in Civil Law doctrine and court practice. The legal nature of the contract of adhesion has been actively discussing within the framework of the Concept on Development of General Provision of Russian Law on Obligations of 2009 and Draft Law on Amendments of the Civil Code of the Russian Federation which was developed on the basis of this Concept. Moreover, understanding of the legal nature of unfair terms in contracts of adhesion has a practical value for exercising a proper judicial control of fairness and guaranteeing the effective protection of the weak contractual party.

\section{Results and Discussions}

\subsection{The Definition of Contract of Adhesion in Russian Contract Law}

\subsubsection{The Problems of the Definition}

The definition of "le contrat d'adhésion" was introduced by French scholar Raymond Saleilles in the beginning of 20th century. It quickly took root first in French and afterwards in world Civil Law doctrine. Analyzing the provisions of German Civil Code, Saleilles pointed out in his study that "there are so-called contracts which are only named after contract, without having the legal structure...contracts of adhesion, where one will significantly prevails the other one and serves as an unilateral declaration of will dictating its terms not so much to an individual as to an indefinite number of people" (Saleilles, 1901).

It must be noted that unlike most of the countries where conclusion of contracts on standard terms are regulated by law and contract of adhesion is a mere legal doctrine, in the Russian Federation the notion of "contract of adhesion" is directly fixed in law. In accordance with article 428 of the Civil Code of the Russian Federation a contract of adhesion is a contract whose terms are determined by one of the parties in printed forms or other standard forms and that may be accepted by the other party not otherwise than by adhering to the proposed contract as a whole.

Immediately after introducing of the First Part of the Civil Code the scholars noted the defects in legal regulation of the contract of adhesion as well as insufficiency of a doctrinal study in this field, which modo legislatoris caused a very limited application of article 428 by the courts. 
First of all, attention must be drawn to the inaccuracy of the definition proposed by Saleilles. Apparently, contracts "of something" can’t exist (Dereux, 1910; May, 1953; Kabalkin, 1996; Tsyplenkova, 2002). This insignificant at first sight terminological inaccuracy veils the nature of the contract of adhesion, giving a clue to the genuine understanding of its legal regulation.

G. Dollat precisely noticed that a free negotiation is not an issue of consideration in the contracts of adhesion. Such assent (l'adhésion) doesn't constitute an element of common will causing contractual relationships, it's a mere condition, which affects the party's obligation to be bound by accepted declaration of will. Developing this idea, L. Tal pointed out that the contract of adhesion is a contract concluded by expressing of assent (par adhésion), but not a contract of expressing of assent (Tal, 2010).

Obviously the party accepts not the contract, but its terms, determined by one of the parties in printed forms or other standard forms. Logical mistake made by the legislators in the definition of the contract of adhesion causes theoretical difficulties in determing its legal nature. Literal interpretation of the article 428 of the Civil Code of the Russian Federation leads to the conclusion that all contractual terms must be determined only by one party whereas the other one is obliged to accept these terms without any changes. Such interpretation gave rise to a very popular in doctrine opinion that the acceptance of the proposed contract en bloc constitutes one of the necessary features of contract of adhesion.

Actually parties negotiate some significant terms upon entering into a contract whereas the rest terms which have been formulated in advance are accepted by the party by adhering to them. In this case the party adhering to the contract is deprived of the right to demand the rescission or change of the contract under the special rules of article 428 of the Civil Code. It leads to the situation when the balance of rights and obligations is violated and one of the parties benefits from one-side formulation of the contract terms while the other one can't demand a protection provided for by the provisions of article 428 of the Civil Code, since a term or several of them were individually negotiated. Obviously this can't in itself indicate a legal equality of the parties (Rakoff, 1983). Here we face with a gross inequality of bargaining power.

We suppose that correcting of a terminological mistake containing in article 428 of the Civil Code significantly changes the definition of the contract of adhesion. It'd make possible to apply general provisions on rescission or change of the contract only to individually negotiated terms. To the contrary, the terms which the other party adhered to without any negotiation can be regulated by article 428 of the Civil Code, establishing the right of a party adhering to the contract to demand the rescission or change of the contract if it contains clearly burdensome terms (Tsyplenkova, 2002).

It should be noted that Russian courts have been holding legal positivism in relation to qualification of contract of adhesion for a long time, and a claim on rescission or change of the contract were granted only in cases when all terms were accepted by the adhering party as a whole. The priority was given to article 426 devoted to public contracts. According to this article a public contract is a contract concluded by a commercial organization and establishing its duties for the sale of goods, doing of work, or rendering of services that this organization, by the nature of its activity, must make with respect to everyone who applies to it (retail trade, carriage by transport for common use, communications services, energy supply, medicine, hotel service, etc.). A commercial organization does not have the right to provide priority to one person before another with respect to conclusion of a public contract, except in cases provided by a statute or other legal acts. This article doesn't protect the weak party against unfair terms since the courts may revise such contracts only if they find their terms to be in contradiction with the provisions of law.

However the situation has recently changed and nowadays Russian courts more often appeal to teleological interpretation of article 428 of the Civil Code. For instance, according to para. 2 of the Informational Letter of the Presidium of the Supreme Commercial Court of the Russian Federation the fact that some terms in credit agreement (the loan amount, repayment period etc.) have been individually negotiated by the parties does not exclude the application of article 428 of the Code to the rest of the terms which the other party had to accept.

In para. 11 of the Resolution on Freedom on Contracts and Its Limitations the Plenum of the Supreme Commercial Court of the Russian Federation stated: "When in time of a conclusion of contract which has been drafted in advance by one party and contained clearly burdensome clauses causing a significant imbalance in the parties' interests (unfair terms) while the other party has been put in a position precluding negotiation of the other content of a separate terms (weak contractual party) the court can apply to such contract the provisions of para 2 of article 428 of the Civil Code and rescise or change of the contract at the request of the party.

Upon discussing the Concept and the Draft Law on Amendments of the Civil Code a lot of concerns about the scope of judicial discretion were expressed due to the proposal of including of the principle of good faith in 
article 1 of the Civil Code. We suppose that regardless of establishing of the principle of good faith in article 1 of the Civil Code only in 2013 it has already been implicitly reflected in para. 2 of article 428 of the Code. Expanding the scope of judicial discretion with respect to contracts of adhesion for protecting of the weak party is an urgent task, especially in cases when they contain unfair terms.

\subsubsection{Features of the Contract of Adhesion}

As it follows from para. 1 of article 428 of the Civil Code in order to be classified as the contract of adhesion an agreement must meet two requirements: terms must be determined by one of the parties in printed forms or other standard forms (a); acceptance of such terms must be complete and indisputable, i.e. the party must adhere to them en bloc and can't change their content upon entering into a contract (b). Thus, the terms of contract of adhesion are formulated in advance for a multitude of contracts. Nevertheless the priority must be given to the second requirement, i.e. a special way of entering into a contract, since it entails significant consequences affecting procedural and substantive interests of the parties. This approach is also supported by the Constitutional Court of the Russian Federation in the Ruling No. 888-O-O on 17 June 2010.

We don't agree with the authors who consider a way of determining of contractual terms to be the main criterion characterizing a legal nature of contract of adhesion. They points out that there is no any special way to conclude the contract of adhesion, since the way in question doesn't differ from the classical one: a complete acceptance (stipulatio ) corresponds to an offer (standard form) (Klochkov, 2000; Saveliev, 2010).

As French scholars notice, contract of adhesion is almost the first contract in the world. F. Testu pointed out that being asymmetrical by its nature all "contracts" in archaic Roman law were concluded upon pronouncing solemn speeches, which one of the parties (who apparently didn't have initiative to utter it) responded by using a word strictly complying with the wording of the question (Spondesne mihi dare Centum?-Spondeo) (Testu, 1993). To take on certain obligations, the weak party was enough to correctly pronounce verba solemnia. The notion exceptio doli was introduced in Praetorian justice only later for changing existing way of concluding the contract. Therefore making and analogy between the stipulation and a free mutual agreement doesn't seem correct.

We agree with the opinion that the main characteristic of contract of adhesion is not a complete and indisputable acceptance of standard terms but impossibility of the party to accept them on the other conditions. The model of concluding contract by adhering to its terms which have been formulated in advance constitutes an abbreviated version of a classical model of concluding the contract (Suhanov, 2010). In substance this point of view doesn't differ from the position expressed by the authors of the present article. The core legal element of the contract of adhesion is an inequality of bargaining power. It has repeatedly been noted by all without exception scholars including R. Saleilles. He specified three main features of the contract of adhesion: 1) it is concluded between parties, one of which has a dominant economic power; 2) the offer is formulated for the use in multiple contracts with an indefinite number of people; 3 ) the terms are determined by one of the parties. To these features later commentators added: (a) the continuing and general nature of the offer, (b) the monopolistic position or at least the great economic power of the offeror, (c) a widespread demand for the goods or services offered, and (d) the use of standard forms of type contracts, the stipulations of which serve mostly the interests of the offeror and the reading, let alone the understanding of which, presents difficulties to the offeree. To this definition nothing substantial was added later; merely the description of the offeror's position was changed to the more modern versions of "superior bargaining power" or "substantive imbalance" (Bolgar, 1973).

Some scholars argued that the party formulating printed forms or other standard forms is a person who is acting for purposes relating to his business in the areas aimed either at the mass consumer, or in the spheres connected with the committing of similar transactions. This approach has been prevailing in Russian doctrine and court practice for a long time. Differentiating the contracts of adhesion and public contracts on the basis of this feature can hardly be justifiable, since the scope of activity doesn't play a key role in qualification of a contract as the contract of adhesion. It will cause a mixture of these two notions.

However, it should be recognized that both public contracts and contracts of adhesion regulate the same phenomenon. Therefore there are reasonable grounds to believe that public contracts are concluded by adhering of the party to its terms, and contrasting these two institutions seems to be incorrect.

Their similarity can also be seen in historical development of the legal regime regulating protection of the economically weak contractual party. The first limitation of freedom of contracts as the basic principle of the period of economic liberalism was connected not with contracts of adhesion but with public contracts. For instance, concluding of the contracts of carriage on terms set by law or regulations with everyone became mandatory for European railways. Afterwards the limitations which were established for the railway transport moved to the sphere of communication, gas and electricity supply etc. The contract of adhesion which already 
had a different meaning was developed later.

In the beginning of the last century L. Tal argued that in contracts of adhesion "one party's will prevails over the other one and dictates its own conditions not already to a particular individual but to an indefinite number of people. On the other hand the party formulated the contractual terms unilaterally bounds itself by certain obligations with respect to the party adhering to them (Tal, 2010).

Thus contracts of adhesion and public contracts have common features. In particular, they were developed for regulation of similar transactions between business and the mass consumer. Without any doubt, both these contracts are aimed at the limitation of freedom of contract in public interests for protecting the weaker contractual party. The scope of application predetermines the use of standard forms upon entering into a contract. Nevertheless we agree with the position that contract of adhesion doesn't coincide with public contract since the latter implies the possibility of a consumer to demand a compulsory conclusion of the contract, whereas contract of adhesion provides a consumer broader than usual opportunity to demand the rescission or change of the contract if it contains clearly burdensome terms (Suhanov, 2010).

New version of article 428 in the Draft Bill doesn't contain any differences in subjective scope of application. Therefore the party regardless of its status as a businessman can demand a special protection provided for by the contracts of adhesion.

\subsection{Unfair Terms in the Contracts of Adhesion}

\subsubsection{The Contours of the Problem}

According to para. 2 of article 428 of the Civil Code of the Russian Federation the party adhering to the contract has the right to demand the rescission or change of the contract if the contract of adhesion, although does not contradict a statute or other legal acts, deprives this party of rights usually given under contracts of such type, excludes or limits the liability of the other party for the violation of obligations or contains other terms clearly burdensome for the adhering party, that it, on the basis of its reasonably understood interests, would not have accepted if it had the possibility of participating in the determination of the terms of the contract.

The Supreme Commercial Court of the Russian Federation in its Resolution on Freedom on Contracts and Its Limitations has departed from legal definition of "clearly burdensome clauses" and for the first time introduced to Russian legal system such notion as unfair contract terms. The Court noticed that as unfair can be regarded terms which cause a significant imbalance in the parties' interests and clearly burdensome to the other party.

The control over fairness is famous to foreign legal systems. The extent to which the courts intervene in the contractual freedom depends on historical development of national law, as well as diverse social, economic and ideological factors etc. Nevertheless according to the approach prevailing in world Civil Law doctrine the judicial control over lawful but unfair terms can be exercised in cases when the party who formulated them violates the requirements of procedural and substantive fairness (Leff, 1967).

Procedural fairness means the abuse by one of the parties of a stronger bargaining power, giving it the exclusive right to determine the content of the contract. The most typical example of inequality of bargaining power is the contract of adhesion.

Substantive fairness tackles the substance of a term, i.e. to what extent it realizes the interests of both parties. In foreign doctrine the substantive fairness if often compared with significant imbalance in the parties rights and obligations to the detriment of those party who adhered to them (Nebbia, 2007).

It's still unclear whether unfair terms are analogous to clearly burdensome clauses specified in para. 2 of article 428 of the Civil Code. To answer this question we should analyze the features of unfair contractual terms.

\subsubsection{Significant Imbalance in the Parties' Interests}

As The Supreme Commercial Court of the Russian Federation stated, unfair terms cause a significant imbalance in the parties' interests. The concept of "significant imbalance" is borrowed from Council Directive 93/13/EEC of 5 April 1993 on unfair terms in consumer contracts.

In our opinion, the notions "significant imbalance in the interests" and "clearly burdensome clauses" differs only terminologically, whereas in substance they have the same meaning. Both of them indicates the excessive infringement of the weak party's interests (significant, clearly). Moreover, both notions demonstrate one-sidedness of a contractual term which makes it disadvantageous to the adhering party.

Despite the fact that some authors also notice the similar nature of the concepts of "significant imbalance" and "clearly burdensome clauses", they nevertheless apply both categories while giving the definition of unfair terms. 
For instance, Y. Fogelson considers that a contractual term shall be regarded as unfair if, contrary to the requirement of good faith, it causes significant imbalance in the parties' rights and obligations and clearly burdensome to the other party (Fogelson, 2010). The same approach was accepted by the Supreme Commercial Court of the Russian Federation in its Resolution on Freedom on Contracts and Its Limitations.

It should be recognized that the only reference to significant imbalance in the parties' interests is not enough for defining legal nature of unfair terms. Otherwise any term which causes a significant imbalance in favor of the party adhering to the contract can be regarded as unfair. Such approach contradicts to the very nature of the protection of the weak contractual party. That's why article 3 of the Directive on Unfair Terms states that the imbalance must be established to the detriment of a consumer (i.e. a party who accepts a proposed terms). To eliminate possible inaccuracies in the interpretation of the provisions related to unfair terms the criterion of a clear burdensomeness was supposed to be included by the Supreme Commercial Court of the Russian Federation in the definition of this legal institution.

However, leaving unfamiliar to Russian courts criterion of balance of interests out of the definition of unfair terms will not affect the content of this concept since as it has been already noticed both these criteria are similar. There are both substantive unfairness of a contractual term and its disadvantageousness to the weak party on hand.

Thus the clearly burdensome clauses being an analogous to the terms causing a significant imbalance in the parties' interests constitute substantive unfairness.

\subsubsection{Different Methods of Adjudication}

The methods of adjudication that courts use in their decision-making process on fairness deserve special attention.

There is no any exhaustive list of the criteria of clearly burdensome terms in Russian legislation. Primarily it is connected with the very nature of unfair terms which may vary from case to case (Karapetov \& Saveliev, 2012). Moreover, too narrow understanding of the institute of the contract of adhesion by Russian courts and therefore small number of cases dealing with the clearly burdensome clauses also prevents us from establishing the criteria of a significant imbalance in case-law practice.

According to para. 2 of article 428 of the Civil Code Russian legislator offers courts to apply the criterion of reasonable interests while considering a fairness of a term. As A. Tsyplenkova notes, the adhering party needs protection not because of this party taking into account its personal interests would never entered into such contract but because of any reasonable person would have done so, i.e. would not conclude contract on the proposed terms (Tsyplenkova, 2002).

Sometimes the fairness test, in cases where a certain term affects the party's statutory rights, revolves around the contract model provided by the legislator (normative expectations).

Within the meaning of para. 2 of article 428 of the Civil Code of the Russian Federation clearly burdensome terms are clauses which deprives the party of rights usually given under contracts of such type.

The "ideally balanced" contract is the one whose terms are established by the legislator itself by means of its dispositive provisions, that is, provisions which set out parties' rights and obligations with reference to each type of contract, which can be derogated by the will of the parties and which therefore only apply where and when the contract does not envisage any different arrangements; and the distance between the situation designed by the law and the one agreed upon by the parties, if not justified or elsewhere compensated, is the significant imbalance (Nebbia, 2007).

Use of "normative expectation"-based arguments is rather common in German law: § 307 BGB expressly states that, in order to assess whether there is "unreasonable disadvantage", one must take into account whether the provision at issue can be reconciled with essential basic principles of the statutory rule from which it deviates.

French author Fin-Langer has proposed four basic criteria to evaluate the fairness on contracts. The criteria are the following: reciprocity, commutability, equivalence and proportionality.

The criterion of reciprocity is fulfilled when both parties to the contract benefit from the same rights and obligations. In other words, if a clause confers the same rights on both parties or equally applies to both, it is reciprocal.

The criterion of commutability widens the field of analysis to the entire contract and refers to the notion of considerations. Commutability exists if a clause, which imposes obligations only on one of the two parties, is 
justified by the existence of another clause, imposing an obligation on the other party, which may be seen as consideration for the first clause or which reduces its adverse effects.

The criterion of equivalence relates to the value of the parties obligations. The application of this criterion is especially straightforward when there is a commonly accepted method of evaluating a contribution in monetary terms as, for example, with respect to credit or insurance risks.

Proportionality requires that any legislative action limiting fundamental rights have a sufficiently important purpose, and that both the means employed to achieve this objective, as well as their effects on individuals' fundamental rights, appear proportional to the importance of the objective sought (Fin-Langer, 2002).

The approach of American courts to adjudication of significant imbalance deserves special attention. They notice in their decisions that no precise definition of substantive unfairness can be proffered. Cases have talked in terms of "overly harsh" or "one-sided" results (as to "shock the conscience"). However, some author points out that "... unconscionability turns not only on a 'one-sided' result, but also on an absence of 'justification'for it". The most detailed and specific commentaries observe that a contract is largely an allocation of risks between the parties, and therefore that a contractual term is substantively suspect if it reallocates the risks of the bargain in an objectively or unreasonable or unexpected manner.

\subsubsection{Good Faith}

Good faith was not mentioned in the definition of unfair terms introduced by the Supreme Commercial Court of the Russian Federation. Nevertheless, some scholars emphasize the necessity of referring to this principle while determing the legal nature of unfair terms. For instance, Y. Fogelson identifies unconscionable conduct of the party upon entering into a contract with the procedural unfairness. According to this approach good faith has a procedural meaning, having to do with an abuse of an unequal bargaining power by one of the parties. In other words, assessment of good faith would include verifying whether the party had an opportunity to influence the terms, whether he had been able to exercise any choice in agreeing to the terms or had any alternatives. In this respect, procedural good faith appears to be aimed at remedying any possible market failure in the form of lack of choice (Nebbia, 2007). Therefore, a contractual term can be considered as unfair only if two requirements are met: 1) it causes significant imbalance in the parties' rights and obligations; 2) it's in contradiction with the principle of good faith.

Some authors outline that the violation of the principle of good faith is already implicitly reflected in the substantial fairness. Good faith involves an overall evaluation of the interests involved, that is, it is related to the contractual terms themselves and focuses on whether and to what extent a term realizes the interests of the party. Good faith does more than exclude certain types of unacceptable conduct and includes terms causing such an imbalance that they should always be treated as being contrary to good faith and therefore unfair; or that good faith encompasses all instances where one party has abused the social practice of making promises either by encouraging misplaced reliance or by securing an unduly advantageous transaction. (Beatson \& Friedmann, 1995; Collins, 1994). As I. Novitskiy notes good faith means "awareness of the other party and its interests". This approach tends to confine the role of "good faith" to that of being either a merely substantive requirement or of being "ancillary" to significant imbalance.

This position of course deserves attention. However, we suppose that in the context of protection of the weak party against unfair terms the violation of good faith has a procedural meaning, i.e. it can be regarded as an abuse of unequal bargaining power by one of the parties. Otherwise the court will have a right to exercise the control over fairness in all type of contracts, irrespectively to whether their parties were able to influence its content or not. Such an approach to judicial control over contracts will negate the value of freedom of contract as one of the basic principles of Contract Law.

Thus, the combination of significant imbalance and violation of good faith characterize the legal nature of unfair terms most accurately.

However, the reference to the violation of the principle of good faith in para. 2 of article 428 of the Civil Code in not required. Contract of adhesion is a typical example of inequality of bargaining power. A party who includes clearly burdensome clauses in the contract using its unique right to determine the standard terms a priori acts in contradiction with good faith.

It also should be noted that the control over fairness of the contract is a legal remedy against the terms which although does not contradict a statute or other legal acts but cause a significant imbalance in the parties rights and obligations. Therefore the terms which don't comply with the provisions of law can't be regarded as unfair as some authors consider (Kratenko, 2012). They are void in accordance with article 168 of Civil Code as not 
corresponding to the requirements of a statute.

The analysis of national legislation has shown that the institute of unfair terms is familiar to Russian Contract Law. It's regulated by para. 2 of article 428 of the Civil Code of the Russian Federation which contains both procedural unfairness (vices in bargaining process) and substantive unfairness (a clear burdensomeness of a term in question). By combining these features together, The Supreme Commercial Court of the Russian Federation developed important to Civil Law doctrine the definition of unfair contract terms.

2.3 Contracts of Adhesion in the Concept on Development of General Provision of Russian Law on Obligations and Draft Law on Amendments of the Civil Code of the Russian Federation

The definition of the contract of adhesion in the Concept and Draft Law does not suffer any changes. The same applies to the consequences of the inclusion of clearly burdensome clauses in the standard form. Therefore Russian legislator doesn't follow the example of some foreign countries which declare the nullity of unfair terms and enhances legal remedies against clearly burdensome clauses by supplementing para 2 of article 428 of the Civil Code with the following provision: "if the contract was changed or rescinded by the court at the request of the adhering party the contract is considered to have been in effect in amended version or to have not had force since it was concluded, unless otherwise established by law or follows from the nature of obligation".

According to para. 3 of article 428 of the Civil Code in the presence of the circumstances provided by Paragraph 2 of the present Article, a demand for the rescission or change of the contract made by the party that adhered to the contract in connection with the conduct of its entrepreneurial activity is not subject to satisfaction if the adhering party knew or should have known on what terms it was concluding the contract.

While preparing the Draft Law on Amendments of the Civil Code of the Russian Federation the drafters proposed the other version of para. 3 which runs: "the provisions of para. 2 of article 428 of the Civil Code can be applied also to contracts formulated by one of the parties, which although don't meet the requirements of the contract of adhesion but place the other party in a position precluding the negotiation of the other content of some terms.

Thus article 428 of the Code will be considered to contain two types of contract: the contract of adhesion and the contract concluded in the situation of inequality of bargaining power. Despite the fact that the Draft Law is still discussing in the Parliament, the Supreme Commercial Court of the Russian Federation has already implemented these approaches in the Resolution on Freedom on Contracts and Its Limitations.

However, the model of protection of the weak party, proposed by the drafters seems to be rather radical, since it significantly extends the scope of judicial control over fairness to all contracts where different kinds of inequality of bargaining power exist. Moreover, the level of protection against unfair terms will be considered the same as to both business to business and business to consumer contracts. It raises some concerns about stability of market economy and party's abuse of the right to change or rescind of the contract.

Legislative consolidation of the contracts where parties are of unequal bargaining power seems to be incorrect since there are no any features defining these contracts as an independent legal institution. Inequality of bargaining power is just one of the characteristics of the contract of adhesion. Although de-jure the drafters remained the definition of the contract of adhesion the same, de facto they changed its meaning.

The definition of the contract of adhesion provided by article 428 of the Civil Code is imperfect and legal regulation of this institution apparently lacks sufficiency. Nevertheless the development of the existing legal regulation of the contract of adhesion is considered to be more appropriate approach in comparison with replacing it with the institute of the contracts concluded by the parties of unequal bargaining power.

In this respect the Civil code of Quebec which also contains definition of the contract of adhesion is a matter of interest. According to article 1379 of Quebec Civil Code a contract of adhesion is a contract in which the essential stipulations were imposed or drawn up by one of the parties, on his behalf or upon his instructions, and were not negotiable.

In our opinion, such an unexpected inclusion of new version of para. 3 in article 428 of the Civil Code indicates the drafter's intention to propose a new solution of problems already existing in court practice rather than suggest a clear and coherent model of developing the contract of adhesion and protecting the weak contractual party.

\section{Conclusion}

The development of large scale enterprise with its mass production and mass distribution increases the importance of the contracts of adhesion. Accordingly, introducing of the uniform approach to determining of the 
legal nature of this institution is an urgent task for Russian Civil Law doctrine. The study of the contract of adhesion as well as proposals on development of its' legal regulation can't be regarded as entirely completed. Obviously both Contract Law doctrine and court practice require further research of this institution based not only on Russian but also world experience.

\section{References}

Beatson, J., \& Friedmann, D. (1995). Good Faith and Fault in Contract Law. Oxford: Clarendon Press.

Bolgar, V. (1972). The Contract of Adhesion a Comparison of Theory and Practice. The 20 American Journal of Comparative Law, 53. http://dx.doi.org/10.2307/839488

Collins, H. (1994). Good Faith in European Contract Law (p. 248).

Dereux, G. (1910). De la nature juridique des “contrats d'adhésion” (p. 504). Revue trimestrielle droit civil.

Dollat, J. (1905). Les contrats d'adhesion. Paris.

Fin-Langer, L. (2002). L'equilibre contractual. Paris: LGDJ.

Fogelson, Y. (2010). Unfair (unconscionable) contractual terms. Economy and Law, 10.

Kabalkin, A. (1996). Commentary to the Civil Code of the Russian Federation (Part 2). Moscow.

Karapetov, A., \& Saveliev, A. (2012). Freedom of Contract and its Limitations (Part 2: The Limitations of Freedom of Contract in Russian and Foreign Law). Moscow: Statute.

Klochkov, A. (2000). Standard terms in commerce: Russian and foreign approach. (Ph. D. Moscow).

Kratenko, M. (2012). Unfair Terms in Loan Agreement: The Tendencies in Court practice and Amendments of Legislation. Russian Laws: Experience, analysis, practice, 5.

Leff, A. (1967). Unconscionability and the Code: The Emperor's New Clause. University of Pennsylvania Law Review. http://dx.doi.org/10.2307/3310882

May, S. (1953). Essay on the General Part of the Bourgeois Law on Obligations. Moscow: Vneshtorgizdat.

Nebbia, P. (2007). Unfair Contract Terms in European Law: A Study in Comparative and EC Law. Portland: Hart Publishing.

Novitskiy, I. (2006). The Principle of Good Faith in the Draft Law on Law on Obligations. Bulletin of Civil Law, $6(1)$.

Popondupulo, V. (2010). Commercial Law. Moscow: Prospect.

Rakoff, T. D. (1983). Contracts of Adhesion: An Essay in Reconstruction. Harvard Law Review. http://dx.doi.org/10.2307/1341009

Saleilles, R. (1901). De la declaration de volonté, contribution a l'étude de l'acte juridique dans le code civil allemand (Art. 116 à 144). Paris: Pichon.

Saveliev, A. (2010). Contract of Adhesion in Russian Civil Law. Bulletin of Civil Law, 5.

Suhanov, E. (2010). Russian Civil Law (Part 2). Moscow: Statute.

Tal, L. (2010). Labor contract, Civil Law Research (Part 2. Domestic legal order of business enterprises). Moscow: Zertsalo.

Tsyplenkova, A. (2002). Contract of Adhesion as a Special Civil Law Category (Ph. D. Moscow).

Vitryanskiy, V. (2011). Special contracts in the Reform on Civil Law. Economy and Law, 10.

\section{Copyrights}

Copyright for this article is retained by the author(s), with first publication rights granted to the journal.

This is an open-access article distributed under the terms and conditions of the Creative Commons Attribution license (http://creativecommons.org/licenses/by/3.0/). 